\title{
Integrated reporting education and hegemonic domination
}

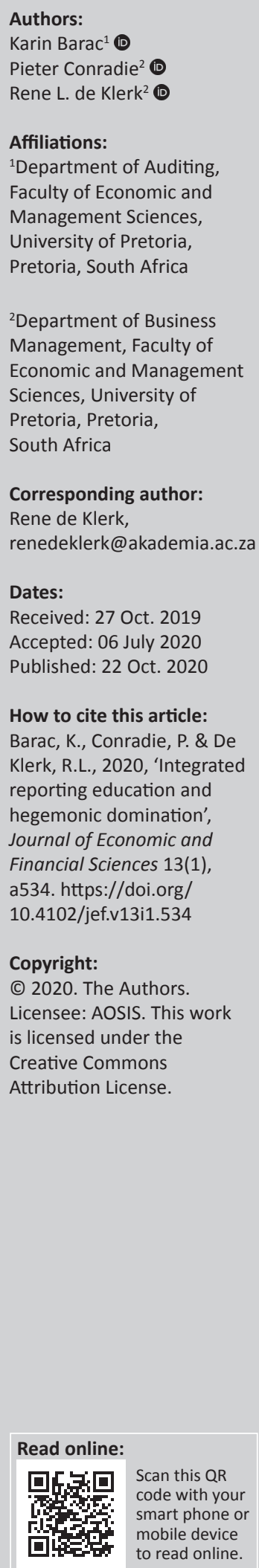

Orientation: Conventional accounting education is presented from a business perspective that rationalises the prioritisation of shareholder interests. Such a paradigm, viewed as the hegemony of business, fails to deliver on the emancipatory intent of social and environmental justice.

Research purpose: To determine whether a postgraduate diploma in integrated reporting (PGDIR) (advancing the principles of social and environmental justice) offered participants an explicitly transformative experience.

Motivation for the study: As educators, first, the authors set out to determine whether graduates of the PGDIR achieved a critical awareness of the tension between sustainability and the hegemony of business, and second, they wanted to determine whether the PGDIR prepared students to deal with hegemonic domination in practice.

Research approach/design and method: In this qualitative study, the first 4 years PGDIR graduates were interviewed.

Main findings: Postgraduate diploma in integrated reporting graduates, after critical selfreflection, expressed a sense of disillusionment arising from having attempted to implement the theory presented in the PGDIR. Whilst prior studies have identified critical thinking skills as necessary components of critical accounting education, this study suggests the need for emotional intelligence, and skills in consultation and negotiation as equally important tools to empower graduates to deal with hegemonic tension in practice.

Practical/managerial implications: The findings of the study could inform accounting pedagogies, as it explains how integrated reporting, with its purpose of advancing the principles of social and environmental justice, was taught in the PGDIR.

Contribution/value-add: The PGDIR, the object of the study, is based on the principles of social and environmental justice and provides insights into the way that these concepts can be taught in a progressive way.

Keywords: integrated reporting; accounting education; hegemony; critical awareness.

\section{Introduction \\ Orientation}

Conventional accounting education is presented from a business perspective that rationalises the prioritisation of shareholder interests (Gray, Bebbington \& McPhail 1994; Gray \& Collison 2002; Saravanamuthu 2015). Such a paradigm, viewed as the hegemony of business, fails to deliver on the emancipatory intent of social and environmental justice (Spence 2009). By inculcating students with values heavily influenced by this hegemonic business perspective (Ferguson et al. 2005), accounting educators cement the hegemony of business (Mayo 2008), thus fuelling hegemonic domination.

\section{Research purpose and objectives}

This study focuses on a postgraduate programme (postgraduate diploma in integrated reporting [PGDIR]) that is based on principles of social and environmental justice - and starkly different from 'normal' business values. Based on graduates' views over a 4-year period, the study's purpose was to determine whether the PGDIR offered students an explicitly transformative experience. To assess whether the purpose was achieved, the study answered two research questions: First, did graduates of the PGDIR achieve a critical awareness of the tension between 
sustainability and the hegemony of business? Second, did the PGDIR prepare graduates to deal with hegemonic domination in practice?

\section{Literature review}

Accounting for sustainability has held the interest of researchers for some time (e.g. Lungu, Caraiani \& Dascălu 2012; O'Dwyer \& Unerman 2016), and it is now evident that accounting education scholars are following suit (Boulianne, Keddie \& Postaire 2018; Boyce et al. 2012; Dyball, Thomson \& Wilson 2014; Gray 2013; Grinnell \& Hunt 2000; Hazelton \& Haigh 2010; Kamp-Roelands 2013; Laine 2013). Critics, however, have expressed disquiet about the capacity of conventional accounting education to 'indoctrinate' its students (Boyce et al. 2012; Gray \& Collison 2002; Saravanamuthu 2015). Others refer to its 'staleness', allowing little opportunity to challenge the tenets of the accounting status quo or consider the impact of accounting on society (Venter \& De Villiers 2013). Conventional accounting education is thus perceived as one dimensional, only exposing students to technical material and only in a vocation-focused way that is disconnected from the complexities of the realworld workplace (Boyce 2004; Gray \& Collison 2002; Pathways Commission 2012; Zulkifli 2011). As a result, claims have been made that students lack critical intellectual independence because of the purely technical focus of their education (Boyce 2004; Ferguson et al. 2005; Gray \& Collison 2002). Accounting students were thus 'simply ... unaware that moral and social choices lay beneath their acceptance of the world according to accounting and/or that cogent alternatives actually exist' (Gray \& Collison 2002:813). In contrast, the broader society holds high expectations of accounting education; it should empower students to advance the well-being of their profession, their organisations and society at large (Adams 2015; Boyce 2004; Dyball \& Thomson 2013; Gray \& Collison 2002; Lawson et al. 2014).

Moving accounting for sustainability from the sidelines into mainstream accounting education is one way in which students could be taught to challenge hegemonic domination (Boyce et al. 2012). Such a shift is a progressive step towards ensuring that accounting education plays a constructive role in creating socially and environmentally attuned accounting professionals and citizens (Dyball et al. 2014; Hazelton \& Haigh 2010). Tensions between conventional accounting education and sustainability accounting are widely reported in the literature (e.g. Boulianne, Keddie \& Postaire 2018; Gray 2013; Thomson \& Bebbington 2004). However, studies that highlight areas of commonality in accounting education (such as curriculum and instruction, students' approaches to learning and their skills and characteristics [Apostolou et al. 2013, 2015, 2017]) make little reference to sustainability accounting education. This could be ascribed to limited coverage of sustainability within accounting education programmes (Boulianne et al. 2018); that it is presented as a peripheral or non-core matter (Marx \& Van der Watt 2013) and that it is mainly taught by individuals who are frequently researchers in the field (Gray \& Collison 2002). As a result, we know very little about the interplay within a sustainability accounting classroom (Gray 2013), nor between its students and the outside world.

This study draws on Gramsci's hegemony perspective (Gramsci 1971) and follows a qualitative approach. It is based on the views of a South African university's PGDIR graduates from 2013 (the year the course was introduced) through 2016. The findings of the study could inform accounting pedagogies, as it explains how integrated reporting (IR), with its purpose of advancing the principles of social and environmental justice, was taught in the PGDIR. By taking cognisance of the finding that critical self-reflection led to some participants expressing a sense of disillusionment, key shortcomings identified in the PGDIR indicate a failure to develop skills, insights and dispositions sufficiently robust to equip graduates to deal with hegemonic domination in practice, and these open up areas for future research. Such information could assist business and accounting academics to adjust their programmes to promote critical engagement in a transformative manner on sustainability matters.

The study was conducted at a South African university, which presents a distinct context. The country's apartheid legacy informed social and environmental governance processes (De Villiers, Rinaldi \& Unerman 2014). Subsequent to the establishment of full democracy in 1994, social, economic and political change enabled IR to become an essential business practice in South Africa (SA), as well as a listing requirement of the JSE Ltd (De Villiers et al. 2014; IoDSA 2009, 2016; Solomon \& Maroun 2012). Integrated reporting represents a move from traditional, narrowly defined accountability to shareholders towards an awareness of the wider needs of society and thus driving change in organisations' focus (Kamp-Roelands 2013). In contrast with the siloed thinking encouraged by traditional reporting, IR calls for the integration of thinking and reporting (exploration of interrelationships between the contents of various business siloes), which the International Integrated Reporting Committee (IIRC) envisaged, would result in 'efficient and productive capital allocation' which could 'act as a force for financial stability and sustainability' (IIRC 2013:2). This can only be achieved, according to Flower (2015), when sustainability is addressed by following a stakeholdercentred approach rather than the shareholder logic-informed status quo. Adams (2015), taking a more accommodating stance, maintains that IR opens up the discursive space that can potentially change actors' thinking and direct further integration of sustainability actions. The PGDIR, the object of the study, is based on the principles of social and environmental justice and is presented from a social and environmental justice perspective.

An overview of recent IR literature in the South African context shows that researchers ask important questions about whether trajectories of IR and IR research in SA can challenge the hegemonic position of business. Most IR research in SA 
focuses on IR quality (Buitendag, Fortuin \& De Laan 2017; Du Toit 2017; Du Toit, Van Zyl \& Schütte 2017; Malola \& Maroun 2019; McNally, Cerbone \& Maroun 2017), whilst issues related to investor's needs also receive attention (Horn, De Klerk \& De Villiers 2018; Johnson, Mans-Kemp \& Erasmus 2019; Naynar, Ram \& Maroun 2018). Another stream of IR research, which has not gained much momentum, considers the way that IR practice evolves (Le Roux \& Pretorius 2019; Raemaekers, Maroun \& Padia 2016) and other practice-related issues (Engelbrecht, Yasseen \& Omarjee 2018; Mmako \& Van Rensburg 2017).

Research on IR quality uses various perspectives. For example, McNally et al. (2017) followed a qualitative approach and interviewed preparers of integrated reports to determine the challenges experienced in preparing an integrated report. They found that the main challenge resided in the fact that IR processes did not fit well with the existing reporting infrastructure. The fact that preparers were uncertain about investors' interest in IRs questioned the purpose of such reporting and consequently constrained the development of management control processes and supporting accounting infrastructure. Du Toit et al. (2017) used content analysis to determine whether the quality of reporting was improving over time. They found that the quality of reporting in IRs had decreased over time and ascribed it to the fact that preparers were uncertain about reporting requirements.

In a recent study, Malola and Maroun (2019) performed a mixed method study to determine the drivers of IR quality. Through content analysis, they found that IRs primarily focused on symbolic and qualitative information rather than substantive quantitative information. They also found that organisations with higher quality IRs had them externally assured and complemented these reports with separate sustainability reports. Du Toit's (2017) major concern was with the readability of IRs. Following a mixed method approach, she found that the complexity of disclosures negatively impacted the readability of reports. This finding contradicts previous studies, showing that reports classified as excellent according to the Ernst \& Young reporting awards criteria were more complex in their disclosures (Du Toit 2017).

Apart from considering IR quality, research on IR in SA also considered issues that could affect investor interests. Two studies used quantitative methods (Horn et al. 2018; Johnson et al. 2019) to determine whether either environmental, social and governance (ESG) issues (Johnson et al. 2019) or corporate social responsibility (CSR) (Horn et al. 2018) variables were correlated with firm value. Neither of these studies found conclusive evidence of such a correlation, and both studies had to resort to a detailed disaggregated level analysis to find any correlations. Naynar et al. (2018) used a mixed method approach to determine whether an expectations gap existed between IR preparers and investors. They found that a gap did indeed exist and ascribed it to the fact that preparers did not understand investors' needs.
Two papers considered the way that IR practice was evolving in SA. Based on a single case study, Le Roux and Pretorius (2019) found that IR had a positive influence on sustainability embeddedness. Raemaekers et al. (2016) performed a content analysis to determine trends in risk disclosures and found these to be very much compliance-driven and not designed as an effective stakeholder communication tool.

It is clear from an overview of recent IR research in SA that researchers were primarily concerned to understand what constituted a 'good' integrated report or whether investors would be interested in this information. This focus on IR research can be ascribed to the fact that IR is still an emerging topic in the reporting literature and could not yet be seen as a matured practice. None of the research performed in a South African context directly addressed the issue of shareholder prominence versus a stakeholder-centred approach. Furthermore, the fact that a large proportion of the research focused on investor needs could be an indication that researchers are more likely galvanising shareholder prominence as opposed to challenging it. The only paper that remotely related to the stakeholder theme was Raemaekers et al. (2016), but this paper was not written from a critical perspective, and the stakeholder-related finding was coincidental as opposed to the central focus of the paper.

Against this background, one could criticise the current trajectory of IR research in a South African context for not addressing the fundamental dichotomy that is evident in the Flower versus Adams debate (Adams 2015; Flower 2015). In the IR education section of this article, we consider the impact of the current research focus on IR education in SA.

The remainder of the article is structured as follows. The next section draws on Gramsci's hegemony concept to discuss sustainability accounting, and this is followed by an overview of IR education. Thereafter, the PGDIR is introduced, the research methodology is explained and findings are presented and discussed. The final section of the article presents concluding remarks and identifies areas for future research.

\section{Hegemony and sustainability accounting education}

This study draws on hegemony, a concept contributing to Marxist theory, derived largely from the work of Antonio Gramsci (Gramsci 1971; Litowitz 2000). The concept of hegemony considers how dominance is established and maintained (Xu, Cortese \& Zhang 2013). It explains how the status quo is sustained in parallel with the existence of much larger groups with different political and economic interests (Cooper 1995), and thus, how particular power formations structure society (Spence 2009). Gramsci distinguishes between alternative mechanisms to reach social stability: these are the forceful and coercive power of the state (political society) and the consent of civil society (Stoddart 2007). Social stability is thus conditional on hegemonic action (consensual or coercive), and is carried out by both 
political and civil society in cultural, political, economic and ideological spheres (Cooper 1995).

Ideology, the mental frameworks that individuals use to make sense of the world around them (Yee 2009), plays an important part in legitimising the power of dominant groups (Stoddart 2007) and their maintenance of social control (Yee 2009). Ideology forms an important dimension in Gramsci's concept of hegemony and is seen as 'the "common sense" that guides our everyday, mundane understanding of the world' (Stoddart 2007:201). Ideology dominates social thinking by becoming 'the world view which has been diffused amongst the masses'; it becomes 'absorbed and naturalised', and it is through this process that hegemonic domination becomes a reality (Yee 2009:77). Hegemony thus 'rests on the consent of masses' (Spence 2007:857). Therefore, prevailing conditions and constraints are accepted as 'natural or as common sense' (Ferguson et al. 2005:26).

The accounting profession, being part of civil society and deriving its power from the state's coercive abilities, is a mechanism that is integral to the process that upholds the existing social order and promotes the status quo (Cooper 1995). As a function of its role in society and its intrinsic processes, accounting plays a hegemonic role (Goddard 2002) that serves and advances capitalism (Cooper 1995; McPhail 1999). In addition, accounting education, as institutional influence, acts as a form of hegemony (Ferguson et al. 2005). Educators are not neutral but serve to cement hegemonic domination (Mayo 2008). They do not act as 'ornamental butterflies' but become 'central ideological agents' (Morrell 1986:737), promoting traditional boundaries within which business serves shareholders, rather than adding social, environmental and economic value to a broad range of stakeholders (Adams et al. 2011).

Examples are found in accounting education literature where hegemonic domination is challenged. For example, Gray (2013:21) engaged students in critical dialogue throughout the teaching process, even to such an extent that the educator asserted: 'I explicitly want students who will not sleep at night'. Other accounting education programmes aim to extend sustainability beyond the business case (Boyce et al. 2012; Dyball et al. 2014; Gray 2013; Grinnell \& Hunt 2000; Hazelton \& Haigh 2010; Kamp-Roelands 2013; Laine 2013). It is thus not surprising that social responsibility is gaining ground amongst accountants' competence requirements, not only to develop themselves as human beings but also to contribute to society's sustainability (Correa Ruiz 2013; Dyball et al. 2014).

Sustainability topics are, however, under-represented in accounting education (Apostolou et al. 2013, 2015, 2017; Boulianne et al. 2018; Gray 2013; Grinnell \& Hunt 2000) and in business and management education journals (Adams et al. 2011; Christensen et al. 2007; Hesselbarth \& Schaltegger 2014; Naeem \& Neal 2012; Rezaee \& Homayoun 2014; Rosinko \& Sama 2009). One of the reasons is that existing literature concentrates mainly on accounting education about sustainability, rather than for sustainability (Contrafatto 2013; Gray 2013), a phenomenon comparable with the 'banking' education concept of Freire (2005). In it, teachers share information and make 'deposits' which students receive, memorise and regurgitate, in contrast to an explicit transformative approach, requiring that students develop critical consciousness and adopt responsibilities indicative of active citizens in society (Freire 2005; Hazelton \& Haigh 2010). In support, Thomson and Bebbington (2004:610) maintain that how one teaches critical accounting remains as important as the question whether such education 'can fulfil its emancipatory potential'. They therefore argue that in order to shape the individual and the society's collective values, morality and legitimate conduct, one starts with the education system in both its content and in the manner in which it is disseminated or presented.

\section{Integrated reporting education}

Integrated reporting, as a type of corporate reporting, has emerged and gained in prominence over the past two decades (Burrit \& Tingey-Holyoak 2011; Cheng et al. 2014; De Villiers et al. 2014; James 2014). This can be ascribed to the convergence of a range of usually disparate macro-economic factors (Haller \& Van Staden 2014) such as corporate failures, the periodic global financial crises and high-profile environmental disasters. These events have generated increasing stakeholder pressure on organisations to enhance the transparency of their reporting and extend the reach of their accountability (James 2014; Marx \& Van der Watt 2013). Existing reporting, including social and environmental reporting, is perceived to be lengthy, disconnected and complex, and the need has been recognised for reporting that better discloses corporate interdependencies on a range of multi-faceted issues (Stubbs \& Higgins 2014).

Integrated reporting represents a move from traditional (purely financial) accountability towards an accountability that drives change in organisations and society at large (Kamp-Roelands 2013). This can only be achieved if sustainability is addressed from a perspective that includes the more extensive and socially inclusive stakeholder interests, thus creating value for society at large, as has been promoted by Flower (2015). Whilst the latter notion of value is commendable, some argue (e.g. Flower 2015) that it is not attainable because the integrating discourse has already been subsumed in the dominant discourse of shareholder logic. Adams' (2015) counter argument is that sustainability is not the main purpose of IR. Its support lies in opening up the discursive space, energising the potential to change actors' thinking and directing the further integration of sustainability actions (Adams 2015). Accounting academics will play a critical role in determining what IR becomes as time passes (Adams 2015). They have to widen their teaching perspectives to go beyond the mere reproduction of the content of an integrated report template by including outcomes of broader integrated thinking (Correa Ruiz 2013; Kamp-Roelands 2013; Owen 2013b). Accounting educators have to re-orientate the 
focus of curriculum development to become multidisciplinary and more affective, and adjust their teaching methods (to add and develop the high-level synthesis and evaluation skills) and their assessment practices (by allowing for a more integrative and cross-functional approach) (Correa Ruiz 2013; Owen 2013a; Pathways Commission 2012).

A review of recent research on IR in the South African context revealed that researchers focussed on issues such as reporting quality, investors' interests and matters that could impact the practice of IR. It is clear that these studies do not challenge the current hegemonic position of business and raise the question whether this current movement is influencing the way that IR is being taught at South African universities. The development and teaching of the PGDIR was not influenced by the current research trends in SA as it was deliberately positioned to challenge the hegemonic position of business that is not reflected in the current IR research trajectory in SA.

\section{Research design}

Following a constructivist-interpretive approach, this qualitative study used the views of the PGDIR's graduates from the course's introduction in 2013 until 2016.

\section{Research setting}

The PGDIR was a 1-year, part-time academic programme. An entry requirement for the PGDIR was simply a bachelor's degree. As a consequence, the applications came from graduates with both accounting and non-accounting backgrounds. The PGDIR aimed to deliver an emancipatory experience, enabling students to implement IR with the intention of advancing social and environmental justice. In striving to reach this goal, the PGDIR perceived hegemonic domination 'not as a closed world from which there is no exit' but a limiting situation that can be transformed (Freire 2005), thus envisaging a transformative learning experience (Mezirow 2003).

The PGDIR attempted to assist students to objectively reframe their thinking by critically reflecting on the present business hegemony that shapes perceptions, interpretations, perspectives and beliefs (Saravanamuthu 2015). By presenting a disorienting dilemma, the sustainability discourse students were challenged to redefine business problems (Saravanamuthu 2015:1). Students were expected to deconstruct the notion of hegemonic domination and participate in critical dialogue. By exercising reflective judgement, they had to demonstrate awareness of and to critique social norms and their personal values. It was anticipated that students would transform or reinvent their frames of reference, and develop skills, insights and dispositions able to address hegemonic domination in practice (Mezirow 2003; Saravanamuthu 2015). Acknowledging that the learning process is not linear, but is rather individualistic, recursive and also spiralling (Saravanamuthu 2015), the ultimate goal was to enable graduates of the PGDIR to become fully participating citizens of a healthy, sustainable and just society (Dyball \& Thomson 2013).

The PGDIR comprised five interactive modules of which two were non-core modules (strategic management and strategic communication) and three were core modules, namely contemporary management and leadership (CML), IR frameworks and IR assurance. The core modules were designed with a strong underlying theme of social and environmental justice, which contrasted with the non-core modules that still largely reflected the traditional (dominant) thinking regarding the role of business in society. This dichotomy of approaches opened up opportunities for critical discourse on the role of business in society in the core modules, during which students from divergent backgrounds respectfully engaged in difficult conversations and felt comfortable to express their feelings and opinions. For example, the CML module (a direction-giving module presented in the first semester) included interrogating disorientating dilemmas that were aimed at achieving transformative learning (Mezirow 2003) in course material and assessments, and used critical dialogue to challenge the implicit assumptions of students' world views and the role of business in society. By challenging the dominant economic paradigm, the module provided the philosophical underpinning of the entire programme, grounding it in the stakeholder-inclusive narrative. It paved the way to present IR from a social and environmental justice perspective. The CML module covered learning areas such as world views and social theories, the role of positive accounting theory in supporting neoliberalism, business in society CSR and leadership theories.

Even though the IR frameworks and assurance modules were more practically and technically oriented, CML knowledge provided direction. Thus, a stakeholder-centric view was used to disseminate knowledge on the development and assurance of integrated reports. The non-core modules positioned integrated reports as being strategically focussed (strategic management) and cognisant of stakeholders' interests (strategic communication). These modules relied on pre-existing (mainstream) theory and were not expressly developed to advance the notion of social and environmental justice.

\section{Research participants and sampling methods}

The PGDIR class size was limited to allow for interactive student engagement. Over a 4-year period, 65 students (2013-2016; 2014-2015; 2015-2017; 2016-2017) enrolled for the PGDIR and 47 (2013-2010; 2014-2011; 2015-2011; 20162015) graduated. After obtaining ethical approval, semistructured interviews were conducted with 26 (55\%) graduates of the PGDIR. To represent the demographics of the population in terms of educational backgrounds, a purposive sampling method was chosen to ensure that the sample consisted of students with both accounting and nonaccounting undergraduate degrees. Selecting participants 
from the four cohorts was not carried out to perform a longitudinal analysis, but rather as an attempt to capture the maximum variety of graduates' experiences over the 4-year period. Seven graduates from each of the 2013 and 2014 cohorts and six graduates from each of the 2015 and 2016 cohorts participated in the study. Table 1 presents the participants' background information.

\section{Data collection methods}

Semi-structured interviews were conducted based on questions informed by the literature on the dominant role of business in society to obtain graduate perceptions of the PGDIR. The interviews with graduates from the 2013 and 2014 cohorts were held in 2015, whilst those from the 2015 and 2016 cohorts were held in 2017. All interviews were conducted by the same researcher, and, except for three, these were all conducted in person. The interviews lasted between 30 and $90 \mathrm{~min}$ and averaged approximately $1 \mathrm{~h}$. Interviews were recorded and professionally transcribed; each participant had an opportunity to review their interview transcript and to clarify or amend any of their comments made during their interview.

\section{Data analysis}

The transcribed interviews were manually analysed by one researcher with the assistance of Atlas.ti qualitative data analysis software. The data analysis process involved identifying meaningful categories of ideas and themes; attaching units of data to the appropriate category; revising initial categories and reorganising data according to these revised categories; and developing and testing propositions and conclusions emerging from the data. The other authors then independently reviewed the analysis. A recursive process was followed whereby the data were re-categorised by a second author and together with a third author; they reached consensus on three critical narrative themes in which PGDIR graduates' 'transformative' experience became evident. Throughout the process, any differences regarding interpretation of the data were discussed and resolved collectively.

\section{Ethical consideration}

This article followed all ethical standards for research without direct contact with human or animal subjects.

\section{Results}

In answering the first research question (whether graduates of the PGDIR obtained a critical awareness of the tension between sustainability and the hegemony of business), two themes emerged. These were (1) critical awareness of the role of business in society and (2) hegemonic tension; the findings are presented accordingly.

\section{Critical awareness of the role of business in society}

Focusing on social and environmental justice, the PGDIR presented disorientating dilemmas that allowed graduates to challenge prevailing norms or knowledge (Saravanamuthu 2015). This was evidently successful because most participants believed that knowledge gained from the PGDIR changed

\begin{tabular}{|c|c|c|c|c|c|c|c|}
\hline Variable & Acc UG & Non-Acc UG & $\begin{array}{l}\text { Employed Acc } \\
\text { (related) industry }\end{array}$ & Employed other & Race & Gender & Age \\
\hline P1/2013 & - & v & - & $v$ & White & Female & 36 \\
\hline P2/2013 & $v$ & - & - & $v$ & White & Female & 53 \\
\hline P3/2013 & v & - & v & - & White & Female & 32 \\
\hline P4/2013 & $v$ & - & v & - & White & Female & 34 \\
\hline P5/2013 & - & v & Not disclosed & Not disclosed & White & Female & 33 \\
\hline P7/2013 & - & v & - & $v$ & White & Female & 46 \\
\hline P1/2014 & - & $v$ & - & $\mathrm{v}$ & White & Female & 45 \\
\hline P2/2014 & v & - & $v$ & - & White & Male & 33 \\
\hline P3/2014 & v & - & v & - & Black & Female & 42 \\
\hline P4/2014 & v & - & - & v & Black & Male & 36 \\
\hline P5/2014 & - & $v$ & - & v & White & Female & 32 \\
\hline P6/2014 & v & - & Not disclosed & Not disclosed & Black & Female & 29 \\
\hline P1/2015 & v & - & - & v & White & Male & 34 \\
\hline P2/2015 & - & $v$ & - & $\mathrm{v}$ & White & Female & 58 \\
\hline P3/2015 & $\mathrm{v}$ & & - & $\mathrm{v}$ & White & Female & 36 \\
\hline P4/2015 & - & $v$ & Not disclosed & Not disclosed & Black & Male & Not disclosed \\
\hline P5/2015 & $v$ & - & $\mathrm{v}$ & - & Black & Female & 31 \\
\hline P6/2015 & $v$ & - & - & $\mathrm{v}$ & Black & Male & 32 \\
\hline P1/2016 & $\mathrm{v}$ & - & - & $\mathrm{v}$ & Black & Female & 45 \\
\hline P2/2016 & $v$ & - & $\mathrm{v}$ & - & Black & Female & 29 \\
\hline P3/2016 & - & v & - & v & Mixed race & Male & 52 \\
\hline$P 4 / 2016$ & - & v & v & - & Indian & Female & 29 \\
\hline P5/2016 & $v$ & & - & v & White & Male & 38 \\
\hline P6/2016 & - & $v$ & Not disclosed & Not disclosed & White & Female & 24 \\
\hline
\end{tabular}


their views about the role of business in society. Their critical reflections on the traditional role of business led to the realisation that business needs to serve public interest. Participant 3/2013 argued:

'We can't allow businesses to just keep on for their own self-gain and the only way is to start forcing them to be accountable for it ... [the PGDIR] awakened all these realizations and brought it to the forefront'.

In similar vein, Participant 2/2014 asserted that the 'PGDIR really shapes your thinking ... the concept of integrated reporting made me realize there's more about business than what we were taught about business'. This sentiment was shared by Participants 1/2016 ('It enlightened me more around things that business can do better') and 1/2014 ('[It gave] a much bigger and broader perspective of how [business] should be impacting on communities and also society as a whole'). Participant 2/2014 realised business needs to be doing more than 'just to tick a box ... and keeping them [shareholders] happy'. For Participant 4/2014, the PGDIR was a 'paradigm shift' enabling them to look at business differently, and this was a notion supported by other participants who elaborated on their past narrow views of the role of business: 'It feels a little bit embarrassing, but I think I was aware of some issues before, but very limited ... It wasn't top of mind' (Participant 3/2014); 'I probably had a very different viewpoint going in. I think my views have become more informed' (Participant 5/2013), and:

'Some people might call it shock therapy but ... it was necessary to learn ... companies are prepared to rather pay quite steep environment fines instead of being responsible towards the environment'. (Participant 6/2013)

The majority of the participants were critical of shortcomings in their undergraduate degrees for not creating an awareness of the role of business in society. An interesting observation is that whilst most participants with non-accounting undergraduate degrees shared the notion with their accounting undergraduate degree classmates, their comments were not as critical as those of participants with an accounting undergraduate degree. For example, non-accounting background Participants 1/2013, 7/2013 and 4/2015 stated, respectively: 'I just wish that there was a way of integrating some of the things which I learnt in the programme, integrating them in the undergraduate studies'; and 'I'm disappointed, that in our undergraduate studies and on the MBA the focus [on sustainability] is not enough', and 'The undergraduate, especially Law, you know, you never touch anything like what we almost did in PGDIR'. Participants with an accounting degree were outspokenly critical about the focus on the technical content of the undergraduate offerings, which were driven by rule-based presentations. Illustrative quotes are: 'We're creative within IFRS, or creative within tax law, but you're still within those boundaries ... there was no creation of awareness of anything broader' (Participant 3/2014); 'The way that commerce degrees are presented [is] very much based [on] and influenced by standards ... So it's pretty much "memorise, regurgitate" exercise' (Participant 6/2014); “"These are the rules, apply them" [it's this] kind of course ... at undergraduate level, because in accounting your belief system doesn't get challenged' (Participant 1/2015). Participant 1/2016 summarises their thinking:

'I'm not bashing the accounting profession. It's my profession. It's made me who I am. But the focus is narrow. You shine there because you're a technical person and you get so disconnected [from] some of the societal issues'.

In contrast to the above, various participants commented favourably on the critical dialogue opportunities the CML used to explore prevailing notions about the role of business in society and to challenge them. The following quotes illustrate and summarise their views: 'to hold conversations outside my comfort zone' (Participant 1/2016), 'challenge each other and ... see [up to] where you can push it' (Participant $6 / 2016$ ) and 'voice your opinion even if it was totally different from the rest of the group' (Participant 2/2013). Critical dialogue was further stimulated by the diverse student composition: 'I found it really useful to be in a multidisciplinary class with people who worked in all sorts of different situations' (Participant 5/2013) and 'being able to critically debate different issues and have people's inputs on different schools of thought and different, even gender and race, issues that we discussed at times' (Participant 1/2015).

These critical discussions and debates challenged participants to rethink their own personal responsibilities, and some participants commented that they had then re-aligned their own beliefs and values towards the goal of social and environmental justice. Examples are: 'If I find out ... a company does xyz to the environment ... [and] I was supporting that business, I would definitely either revoke [my support] or do something different' (Participant 4/2013); 'My attitude towards environmental issues has changed' (Participant 6/2015); 'So, personally, I changed my thinking; and also in society and at work, you know, I still continue to apply some of the lessons' (Participant 1/2016); and 'It has resulted in some loss of friends but it has also strengthened some friendships and relationships because you stop being materialistic as well' (Participant 2/2016). This finding points towards re-orientation of these participants' thinking, thus enabling them to replace pre-existing paradigms with new schemas (Saravanamuthu 2015) when their newly awakened critical consciousness compelled an explicitly transformative approach (Freire 2005; Hazelton \& Haigh 2010).

Participant $2 / 2015$, in contrast, was of the opinion that the PGDIR did not meet its emancipating potential: 'I still feel that it's [PGDIR is] too focussed on capitalism, very little utilitarianism when it comes to economic apartheid'. Other participants already held critical views about business in society, and the PGDIR reaffirmed their views: 'I chose this field of work because I wanted to do good in society ... I think it $[P G D I R]$ reaffirmed my beliefs and my roles in my responsibility to society' (Participant 1/2015); 'I felt like there were bigger problems than this but what PGDIR definitely 
did was to solidify whatever little views that I had' (Participant 2/2016); and 'I won't say it changed my view. I've always been an environmentalist, so it's maybe just a linking my environmental background with the sort of business side of things' (Participant 6/2013).

\section{Hegemonic tension}

Participants were confronted with the sharp contrast between business' practice of pursuing profit maximisation and growth, and the counter-narrative presented in the PGDIR's discourse. The majority of them experienced an inner conflict, where the sustainability ethos, representing an emergent perspective, conflicted with such 'normal' practice. We labelled this as hegemonic tension. It occurred where participants perceived that business' rationalisation of shareholder prioritisation (Gray \& Collison 2002; Gray et al. 1994) was to the detriment of social and environmental justice. For example, participant 4/2013 argued that whilst business sees sustainability matters as 'more money to spend ... they don't really see [it] has value in it', and participant 7/2014 recognised that business ignores such matters: 'I don't think necessarily business think they have a responsibility. They are focussed on the bottom line and that is it'. Participants 5/2016 and 5/2013 blamed the difficult economic times: 'Businesses, everybody is currently on a survival mode ... you're not going to worry about the trees, and the grass and the flowers'; and '[business has] to actually focus on finance because if they're no longer financially viable, they're no longer a business'.

Some of the participants went beyond the mere intellectual critique of the embedded business case and emotionally connected with the re-framed reality (Saravanamuthu 2015) of social and environmental justice. For example, participant 5/2015 felt 'very uncomfortable'. Participant 7/2013 felt 'a bit depressed' based on the following observation:

'People are brought up, neoclassical, and [they] think short-term (the bonuses at the end of the year) ... it's so entrenched that I feel a bit depressed to think: how are we going to change the world? I don't know how people are going to think differently'.

Participant 6/2013 even made a career change to work in an environment with less hegemonic tension:

'[During] my exit interview at [a Big 4 firm], when they asked questions regarding, "how do you see the firm's responsibility towards the environment?" and you know, [I had to say] to be frankly honest, it's lacking'.

The overwhelming majority of participants observed that whenever there is talk of or decisions to be made regarding trade-offs between financial capital and other capitals such as environmental or social, the latter were always trumped by financial considerations. According to participant 3/2015, there is no easy solution 'because, to implement the change you need power, and you need to get people with power to buy into [sustainability]'.
Participants' reactions to changes in their critical awareness of the role of business in society with respect to the hegemonic tension were different. We used this outcome to answer the study's second research question, namely: Did the PGDIR prepare graduates to deal with hegemonic domination in practice?

\section{Outcome of critical awareness and hegemonic tension}

Taking all views expressed by participants into account, three outcome categories were identified: (1) optimistic views, (2) more realistic views and (3) views displaying disillusionment. Most participants' views showed a sense of disillusionment about the everyday reality of hegemonic domination. Some participants shared that they had attempted to bring about change in their organisations but were not successful. Thus, Participant 5/2015 reported:

'I went to the CEO to tell him I think our report can be much better, and I mentioned a few things that we do in this group that could be very valuable but ... the CEO said he's happy with the current report. I almost feel like my voice as an accountant here in the company is not necessarily heard ... at the moment that seems very far-fetched that I'm going to change that in this business'.

And Participant 6/2016: 'then you come with these big ideas and they're [condescending] like, "but you haven't experienced the world"'. Participant 7/2013 saw herself as having limited influence:

'Small things; so I've negotiated with the CEO that we don't use water bottles anymore, that we actually use, [you $]$ know, water in jugs, so small things ... there's a lot more that I [need to do]; I feel guilty'.

Others believed that their roles within their organisations did not carry enough weight to enable them to challenge hegemonic domination. For example, Participant 3/2013:

'People are polluting the air and no-one is doing anything about it. And we sit there and we are the auditors and we can't say to them 'this is a problem' because it's not within the scope of what we do';

Participant 4/2013: 'I'm not using as much of that knowledge and that ability in what I do as opposed to what I could be doing'; and Participant 7/2013:

'I feel a bit depressed to think how we are going to change the world; I don't know how people are going to think differently. It's difficult when you've been in the same job for so many years, you've got huge responsibilities; it's, it's difficult to, to change that in the place where you are'.

Participant $1 / 2016$ reluctantly recognised himself as a lone voice:

'We started this programme very positive, thinking that we're going to be part of the group that's going to change the world ... but really, these things do not really exist; you need more people to go through that programme so that you can have masses in [each] organisation that can drive this paradigm shift ... so that you don't have to be the lone voice'. 
Others were left confused: 'Don't expect that you're going to walk away with the world's knowledge [to address sustainability]. You're actually going to walk away with more confusion after the course' (Participant 2/2014); or uncomfortable:

'To help people do a report is not really going to make a difference. That's just a report ... [To] keep having a debate and keep challenging companies to be innovative - I mean, that's the influence I would love to have ... It made me more uncomfortable with what I do'. (Participant 3/2014)

Another participant believed that he was living a lie: 'Sustainability assurance, yes, but for us, it's living the lie. For me it became, I can live a lie every single day. I just couldn't anymore, I had to give up' (Participant 6/2013).

In contrast, seven participants expressed optimistic views. They experienced hope:

'I would like to become much more involved in an in-house function, internally with integrated reporting. [I am having] interactions and conversations with [management] - 'Oh there is a bigger impact' - and that is why I maybe feel there's hope and we can change it. ... Two of those assignments, I end[ed] up [submitting them] to be [in] an internal publication at the firm that I was with because it was so relevant'. (Participant 7/2014)

And some were fascinated: 'The whole integrated thinking within the small and medium sized enterprises, for me, I find it very practical, it's very fascinating' (Participant 6/2015). Participant 1/2014 felt empowered: 'A lot of the things that I've learnt, I've already applied, although there's definitely things I can improve on'; and participant 6/2016 was inspired to make a career change: 'I think it's changed my whole career path like, it really has'.

Five participants' perceptions were more realistic. They saw opportunities to challenge hegemonic domination but realised that it is a not straightforward process. Quotes representative of this mindset include the following: 'It's opened my eyes to the potential of reporting within this sector and how limited it actually is ...' (Participant 1/2015):

'If I'm not going to make a difference, who isn't, you know; and then I realised, this problem is too big ... for me to do anything, and then towards the end [of the course] I also realised that, you know what, I can act as a responsible person in the job that I do (Participant 2/2016);

'It's very easy when you're studying to be quite idealistic because you're in a university situation ... working has certainly made me think. Clearly something's wrong. Clearly something's broken. But to just stop working and close the business is not the way to fix it' (Participant 5/2013);

'I think it made you a realist, that you cannot change things once you've come out of this course. It's a long-term viewpoint but from this $[P G D I R]$ it channelled you on how to focus a little bit within your realm of influence' (Participant 2/2015)

\section{Discussion}

Table 2 presents a summary of participant perceptions. The vast majority of participants believed that the PGDIR challenged their business views, and that they experienced hegemonic tension in practice and criticised their undergraduate programmes for their limited focus on sustainability. The study suggests that participants' perceptions about hegemonic tension could be shaped by their undergraduate exposure. Except for Participant 4/2015, all participants with non-accounting undergraduate backgrounds commented on hegemonic tension, whilst fewer participants with an accounting undergraduate background made similar comments. It therefore appears that hegemonic domination in practice was an upfront issue for participants with non-accounting undergraduate backgrounds, as they felt compelled to comment on the matter. A reason why participants with an accounting background (they were working mainly in accounting or related fields) were not as vocal about hegemonic tension could be that with corporate social accounting becoming more formalised, it has increased transparency, at least within their employer organisations, of what is being performed and what is possible in the short term. This has closed off rather than opened up discourse on sustainability matters within these organisations (Spence 2007), limiting exposure of these participants to opportunities to expand efforts to address hegemonic tension.

Participants with an undergraduate accounting background were outspoken about the technical content of the undergraduate offerings, which were driven by rule-based presentations. It was also noteworthy that none of the participants mentioned non-technical skills development as having been part of their undergraduate experiences, despite the presence of these skills being widely reported in the literature (e.g. Chaplin 2017; Crawford, Helliar \& Monk 2011; Hassall et al. 2005; Helliar, Monk \& Stevenson 2009; Kavanagh \& Drennan 2008). It raises the possibility that rule-based and compliance-driven tangents of accounting are so pervasive and confining (Boyce 2004) that hegemonic tension, in practice, is seen by those with an accounting education as a matter to be dealt with in a similar rulesbased manner, thus obviating the need to consider use of non-technical skills.

Most participants commented favourably on the critical debates held in class, which required reflection and reflective judgement, which are skills embedded in transformative learning pedagogy (Saravanamuthu 2015). This is an indication the PGDIR used IR debates to open up discursive space in which heretic discourse was allowed to challenge dominant shareholder-as-prime-beneficiary positions. Whilst the majority of participants perceived the PGDIR to have challenged their views, only a few of them reported that their own beliefs and values had fundamentally changed. It appears therefore as if these latter participants experienced the PGDIR as a transformative learning experience, resulting in re-invention of their belief systems (Mezirow 2003; Saravanamuthu 2015), and suggests that the PGDIR has the potential to be an emancipatory learning experience for them 
TABLE 2: Summary of findings per participant.

\begin{tabular}{|c|c|c|c|c|c|c|c|c|c|c|c|c|c|}
\hline \multirow[t]{2}{*}{ Participant } & \multicolumn{2}{|c|}{$\begin{array}{l}\text { Undergraduate } \\
\text { background }\end{array}$} & \multicolumn{2}{|c|}{ Current employment } & \multicolumn{3}{|c|}{$\begin{array}{l}\text { Impact of PGDIR on } \\
\text { views about business }\end{array}$} & \multirow{2}{*}{$\begin{array}{c}\text { Impact of } \\
\text { the PGDIR } \\
\text { on personal } \\
\text { views }\end{array}$} & \multirow{2}{*}{$\begin{array}{c}\begin{array}{c}\text { Experience } \\
\text { inner } \\
\text { conflict? }\end{array} \\
\begin{array}{c}\text { Hegemonic } \\
\text { tension }\end{array}\end{array}$} & \multirow{2}{*}{$\begin{array}{c}\begin{array}{c}\text { Views RE } \\
\text { undergrad } \\
\text { education }\end{array} \\
\begin{array}{c}\text { UG } \\
\text { weaknesses }\end{array}\end{array}$} & \multicolumn{3}{|c|}{$\begin{array}{l}\text { Outcome of critical awareness } \\
\text { RE hegemonic tension }\end{array}$} \\
\hline & $\begin{array}{c}\text { Accounting } \\
\text { UG }\end{array}$ & $\begin{array}{l}\text { Non- } \\
\text { Accounting } \\
\text { UG }\end{array}$ & $\begin{array}{l}\text { Employed: } \\
\text { Accounting } \\
\text { industry }\end{array}$ & $\begin{array}{l}\text { Employed: } \\
\text { Other }\end{array}$ & $\begin{array}{c}\text { Challenge } \\
\text { business role }\end{array}$ & $\begin{array}{c}\text { Reaffirm } \\
\text { business } \\
\text { role }\end{array}$ & $\begin{array}{c}\text { No impact on } \\
\text { business in } \\
\text { society }\end{array}$ & & & & Optimism & Realism & Disillusionment \\
\hline $\mathrm{P} 1 / 2013$ & - & $\mathrm{v}$ & - & $\mathrm{V}$ & $\mathrm{v}$ & - & - & - & 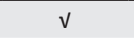 & v & - & - & $\mathrm{v}$ \\
\hline P2/2013 & v & - & - & v & - & - & - & - & - & v & - & - & - \\
\hline P3/2013 & v & - & v & - & v & - & - & - & - & $v$ & - & - & $v$ \\
\hline P4/2013 & v & - & v & - & - & - & - & $v$ & $v$ & - & - & - & $v$ \\
\hline P5/2013 & - & $v$ & - & $v$ & $v$ & - & - & - & $v$ & $v$ & v & v & - \\
\hline P6/2013 & - & $v$ & - & $\checkmark$ & $v$ & $v$ & - & - & $v$ & - & - & - & $v$ \\
\hline P7/2013 & - & v & - & $\checkmark$ & $v$ & - & - & v & v & v & - & - & V \\
\hline P1/2014 & - & $v$ & - & $v$ & $v$ & - & - & $v$ & v & $v$ & v & - & - \\
\hline P2/2014 & $v$ & - & $v$ & - & $v$ & - & - & - & - & v & - & - & $v$ \\
\hline P3/2014 & $v$ & - & $v$ & - & $v$ & - & - & - & - & $v$ & - & - & V \\
\hline P4/2014 & $v$ & - & - & V & $v$ & - & - & - & - & - & - & - & - \\
\hline P5/2014 & - & $v$ & - & V & $v$ & - & - & $v$ & v & $v$ & - & - & - \\
\hline P6/2014 & V & - & $\begin{array}{l}\text { Not } \\
\text { disclosed }\end{array}$ & - & $v$ & - & - & - & v & v & - & - & - \\
\hline P7/2014 & V & - & $\begin{array}{c}\text { Not } \\
\text { disclosed }\end{array}$ & - & $v$ & - & - & - & v & $v$ & v & & - \\
\hline P1/2015 & $v$ & - & - & $v$ & $v$ & $v$ & - & - & - & v & - & $v$ & - \\
\hline P2/2015 & - & $v$ & - & $v$ & - & - & v & - & v & - & - & $v$ & - \\
\hline P3/2015 & $v$ & & - & V & $v$ & - & - & - & v & - & - & & v \\
\hline P4/2015 & - & $v$ & $\begin{array}{c}\text { Not } \\
\text { disclosed }\end{array}$ & - & $v$ & - & - & - & - & v & - & v & - \\
\hline P5/2015 & $v$ & - & v & - & $v$ & - & - & - & v & - & - & - & $v$ \\
\hline P6/2015 & V & - & - & V & $v$ & - & - & $v$ & v & v & v & - & - \\
\hline P1/2016 & $v$ & - & - & $v$ & $v$ & - & - & $v$ & v & v & - & - & $v$ \\
\hline P2/2016 & $v$ & - & $v$ & - & - & $v$ & - & v & - & v & - & v & - \\
\hline P3/2016 & - & $v$ & - & v & $v$ & - & - & - & v & - & v & - & - \\
\hline P4/2016 & - & $v$ & $v$ & - & - & - & - & v & v & - & v & - & - \\
\hline P5/2016 & v & - & - & v & $v$ & - & v & - & v & - & - & - & $v$ \\
\hline P6/2016 & - & $v$ & - & $\begin{array}{c}\text { Not } \\
\text { disclosed }\end{array}$ & v & - & - & - & v & - & v & - & $v$ \\
\hline
\end{tabular}

$\checkmark$, relevant information provided, comment made or view expressed.

(Thomson \& Bebbington 2004). The remaining participants, and particularly those from accounting backgrounds, could have perceived hegemonic domination as 'a closed world from which there is no exit' (Freire 2005).

Based on their perceptions, participants' views were categorised as being (1) optimistic, (2) more realistic or (3) demonstrating a sense of disillusionment. As half of the participants reported a sense of disillusionment, one could question whether the PGDIR, in fact, succeeded in developing graduates' skills, insights and dispositions (Mezirow 2003; Saravanamuthu 2015) to deal with hegemonic domination in practice. In particular, this finding suggests that graduates need assistance with developing their emotional intelligence, and consultation and negotiation skills. Emotional intelligence will assist a graduate to understand him or herself as well as other people, thus addressing both intrapersonal (self-awareness and self-management) and interpersonal (awareness of others and relationship skills) aspects of business interactions (Salovey \& Mayer 1990). As the aforementioned aspects are interrelated, a student should develop the capability of emotional understanding of hegemonic domination whilst also equipping him or her to handle social relationships (Goleman 1998). In addition to cultivating consultation and negotiation skills, relying on good communication skills will enable the graduate to resolve a divergence of interests in practice, whether they are real or perceived, in situations where common interests also exist (Anastakis 2003).

\section{Conclusion}

This study explored hegemonic domination in the context of business and accounting education. It aimed to determine whether graduates of the PGDIR, aiming to advance the principles of social and environmental justice, offered an explicitly transformative experience. This objective was reached by determining whether the graduates obtained a critical awareness of the tension between sustainability and the hegemony of business, and were prepared to deal with hegemonic domination in practice. Views of graduates indicated that the PGDIR succeeded in presenting them with a counter-narrative. The PGDIR, however, left many participants with a sense of disillusionment, suggesting that it did not prepare graduates to deal with practical business world trade-offs. Whilst prior studies identified the need for critical thinking skills to make sense of critical accounting education (e.g. Boyce 2004), our study suggests the need to cultivate emotional intelligence and develop consultation and negotiation skills to empower graduates to deal with 
hegemonic tension in 21st century business practice. Future studies could explore how emotional intelligence (those emotional, personal and social abilities and skills influencing a graduate's ability to cope effectively with environmental demands and pressures [Carmeli 2003]) should be developed in critical accounting programmes so that they are able to deal with realities that contrast and challenge their critical consciousness, thus enabling graduates to assume the responsibilities of active citizens in society (Freire 2005; Hazelton \& Haigh 2010). Previous research has indicated that experiential learning and simulations have been effectively used as teaching tools to develop consultation and negotiation skills (Nadler, Thompson \& Van Boven 2003), and accounting educators could explore introducing these in critical accounting programmes.

Even though the PGDIR was designed to be an emancipatory experience, it was found that only a limited number of participants reported having had an explicitly transformative experience. Only a few participants' views indicate that the PGDIR changed their personal beliefs and values. Saravanamuthu (2015) acknowledges that the re-invention phase of transformative learning is not always guaranteed, which raises the question: why were some participants more open for transformative thinking than the majority of their peers? Various aspects need to be considered to answer such a complex question. Our study did not reveal differentiating patterns based on student profiles. Future studies could explore these: for example, how does culture influence behavioural intentions to change beliefs and values in relation to sustainability.

Building on the Gramscian conception that ideas are developed and constructed at various levels throughout society (Spence 2007), future studies could explore hegemonic tension in relation to IR. It will be interesting to determine how such tension in an organisation is managed and communicated, and whether these can be indicative of the ideology articulated in IR.

The study is not without limitations. Although the interview method provides rich, in-depth information, it is based on participants' views that usually include an element of bias in favour of the status quo (Lander, Koene \& Linssen 2013). The study was limited to the South African context and to a specific academic offering, the PGDIR, at a single residential university. Although the findings may not be generalisable, the study provides a platform for accounting and business academics to become instrumental in determining what IR becomes in the years ahead (Adams 2015).

\section{Acknowledgements Competing interests}

The authors declare that they have no financial or personal relationships that may have inappropriately influenced them in writing this article.

\section{Authors' contributions}

All authors contributed equally to this work.

\section{Funding information}

This study was funded by the British High Commission; Department of Business Management, University of Pretoria; Department of Auditing, University of Pretoria.

\section{Data availability statement}

The data generated in this qualitative study can be made available upon reasonable request from the corresponding author.

\section{Disclaimer}

The views and opinions expressed in this article are those of the authors and do not necessarily reflect the official policy or position of any affiliated agency of the authors.

\section{References}

Adams, C.A., 2015, 'The integrated reporting council: A call to action', Critical Perspectives on Accounting 27, 23-28. https://doi.org/10.1016/j.cpa.2014.07.001

Adams, C.A., Heijltjes, M.G., Gavin, J., Marjoribanks, T. \& Powell, M., 2011, 'The development of leaders able to respond to climate change and sustainability challenges: The role of business schools', Sustainability Accounting, Management and Policy Journal 2(1), 165-171. https://doi.org/10.1108/20408021111162191

Anastakis, D.J., 2003, 'Negotiation skills for physicians', The American Journal of Surgery 185(1), 74-78. https://doi.org/10.1016/S0002-9610(02)01109-1

Apostolou, B., Dorminey, J.W., Hassell, J.M. \& Rebele, J.E., 2015, 'Accounting education literature review (2013-2014)', Journal of Accounting Education 33(2), 69-127. https://doi.org/10.1016/j.jaccedu.2015.04.001

Apostolou, B., Dorminey, J.W., Hassell, J.M. \& Rebele, J.E., 2017, 'Accounting education literature review (2016)', Journal of Accounting Education 39(C), 1-31. https://doi. org/10.1016/j.jaccedu.2017.03.001

Apostolou, B., Dorminey, J.W., Hassell, J.M. \& Watson, S.F., 2013, 'Accounting education literature review (2010-2012)', Journal of Accounting Education 31(2), 107-161. https://doi.org/10.1016/j.jaccedu.2013.03.001

Boulianne, E., Keddie, L. \& Postaire, M., 2018, '(Non) coverage of sustainability within French professional accounting education program', Sustainability Accounting, Management and Policy Journal 9(3), 313-335. https://doi.org/10.1108/ SAMPJ-09-2017-0119

Boyce, G., 2004, 'Critical accounting education: Teaching and learning outside the circle', Critical Perspectives on Accounting 15(4-5), 565-586. https://doi. org/10.1016/S1045-2354(03)00047-9

Boyce, G., Greer, S., Blair, B. \& Davids, C., 2012, 'Expanding the horizons of accounting education: Incorporating social and critical perspectives', Accounting Education 21(1), 47-74. https://doi.org/10.1080/09639284.2011.586771

Buitendag, N., Fortuin, G.S. \& De Laan, A., 2017, 'Firm characteristics and excellence in integrated reporting', South African Journal of Economic and Management Sciences 20(1), 1-8. https://doi.org/10.4102/sajems.v20i1.1307

Burrit, R. \& Tingey-Holyoak, J., 2011, 'Sustainability accounting research and professional practice: Mind the gap', in E. Evans, R. Burritt \& J. Guthrie (eds.) professional practice: Mind the gap, in E. Evans, R. Burritt \& J. Guthrie (eds.), practice, p. 120-123, ICAA and Adelaide: Centre for Accounting, Governance and Sustainability, University of South Australia, New South Wales.

Carmeli, A., 2003, 'The relationship between emotional intelligence and work attitudes, behaviour and outcomes', Journal of Managerial Psychology 18(8), 788-813. https://doi.org/10.1108/02683940310511881

Chaplin, S., 2017, 'Accounting education and the prerequisite skills of accounting graduates: Are accounting firms' moving the boundaries?', Australian Accounting Review 27(1), 61-70. https://doi.org/10.1111/auar.12146

Cheng, M., Green, W., Conradie, P., Konishi, N. \& Romi, A., 2014, 'The international integrated reporting framework: Key issues and future research opportunities', Journal of International Financial Management and Accounting 25(1), 90-119. https://doi.org/10.1111/jifm.12015

Christensen, L.J., Peirce, E., Hartman, L.P., Hoffman, W.M. \& Carrier, J., 2007, 'Ethics, CSR, and sustainability education in the financial times top 50 global business schools', Journal of Education for Business 73(4), 308-317. https://doi. org/10.1007/s10551-006-9211-5

Contrafatto, M., 2013, "Utopia" and "passion": A commentary on "Sustainability and accounting education: The elephant in the classroom"', Accounting Education: An International Journal 22(4), 336-339. https://doi.org/10.1080/0 Education: An Internation
9639284.2013.817797 
Cooper, C., 1995, 'Ideology, hegemony and accounting discourse: A case study of the national union of journalists', Critical Perspectives on Accounting 6(3), 175-209. https://doi.org/10.1006/cpac.1995.1019

Correa Ruiz, C., 2013, 'A commentary on "Integrated reporting: A review of developments and their implications for accounting curriculum"', Accounting Education: An International Journal 22(4), 360-362. https://doi.org/10.1080/096 39284.2013.817800

Crawford, L., Helliar, C. \& Monk, E.A., 2011, 'Generic skills in audit education', Accounting Education: An International Journal 20(2), 115-131. https://doi.org/1 $0.1080 / 09639284.2011 .557487$

De Villiers, C., Rinaldi, L. \& Unerman, J., 2014, 'Integrated reporting: Insights, gaps and an agenda for future research', Accounting, Auditing and Accountability Journal 27(7), 1042-1067. https://doi.org/10.1108/AAAJ-06-2014-1736

Du Toit, E., 2017, 'The readability of integrated reports', Meditari Accountancy Research 25(4), 629-653. https://doi.org/10.1108/MEDAR-07-2017-0165

Du Toit, E., Van Zyl, R. \& Schütte, G., 2017, 'Integrated reporting by South African companies: A case study', Meditari Accountancy Research 25(4), 654-674. https:// doi.org/10.1108/MEDAR-03-2016-0052

Dyball, M.C. \& Thomson, I., 2013, 'Sustainability and accounting education. Gues editorial', Accounting Education: An International Journal 22(4), 303-307. https:// doi.org/10.1080/09639284.2013.817787

Dyball, M.C., Thomson, I. \& Wilson, R.M.S., 2014, Sustainability in accounting education, Routledge, New York, NY.

Engelbrecht, L., Yasseen, Y. \& Omarjee, I., 2018, 'The role of the internal audit function in integrated reporting: A developing economy perspective', Meditari Accountancy Research 26(4), 657-674. https://doi.org/10.1108/MEDAR-10-2017-0226

Ferguson, J., Collison, D., Power, D. \& Stevenson, L., 2005, 'What are recommended accounting textbooks teaching students about corporate stakeholders?', The
British Accounting Review 37(1), 23-46. https://doi.org/10.1016/j.bar.2004.08.002

Flower, J., 2015, 'The international integrated reporting council: A story of failure', Critical Perspectives on Accounting 27, 1-17. https://doi.org/10.1016/j. сра.2014.07.002

Freire, P., 2005, Pedagogy of the oppressed, 30th anniversary ed. Continuum, New York, NY.

Goddard, A., 2002, 'Development of the accounting profession and practices in the public sector - A hegemonic analysis', Accounting, Auditing and Accountability Journal 15(5), 655-688. https://doi.org/10.1108/09513570210448957

Goleman, D., 1998, Working with emotional intelligence, Bantam Books, New York, NY.

Gramsci, A., 1971, Selections from the prison notebooks, The Electric Book Company Ltd., 1999, London, viewed 4 May 2018, from http://abahlali.org/files/gramsci.pdf

Gray, R., 2013, 'Sustainability and accounting education: The elephant in the classroom', Accounting Education: An International Journal 22(4), 308-332. https://doi.org/10.1080/09639284.2013.817795

Gray, R. \& Collison, D., 2002, 'Can't see the wood from the trees, can't see the trees from the numbers? Accounting education, sustainability and public interest' Critical Perspectives in Accounting 13(5-6), 797-836. https://doi.org/10.1006/ cpac.2002.0554

Gray, R.H., Bebbington, K.J. \& McPhail, K., 1994, 'Teaching ethics and the ethics of accounting teaching: Educating for immorality and a case for social and accounting teaching: Educating for immorality and a case for social and
environmental accounting education', Accounting Education 3(1), 51-75. https:// environmental accounting education',
doi.org/10.1080/09639289400000005

Grinnell, D.J. \& Hunt, G.H., 2000, 'Development of an integrated course in accounting: A focus on environmental issues', Issues in Accounting Education 15(1), 19-42. https://doi.org/10.2308/iace.2000.15.1.19

Haller, A. \& Van Staden, C., 2014, 'The value added statement - An appropriate instrument for integrated reporting', Accounting, Auditing and Accountability Journal 27(7), 1190-1216. https://doi.org/10.1108/AAAJ-04-2013-1307

Hassall, T., Joyce, J., ArqueroMontaño, J.L. \& Anes A.D., 2005, 'Priorities for the development of vocational skills in management accountants: A European perspective', Accounting Forum 29(4), 379-394. https://doi.org/10.1016/j. accfor.2005.03.002

Hazelton, J. \& Haigh, M., 2010, 'Incorporating sustainability into accounting curricula: Lessons learnt from an action research study', Accounting Education: An International Journal 19(1-2), 159-178. https://doi.org/10.1080/0963928080 2044451

Helliar, C.V., Monk, E.A. \& Stevenson, L.A., 2009, 'The development of trainee auditors' skills in tertiary education', International Journal of Auditing 13(3), 185-202. https://doi.org/10.1111/j.1099-1123.2009.00385.x

Hesselbarth, C. \& Schaltegger, S., 2014, 'Educating change agents for sustainability e-learnings from the first sustainability management master of busines administration', Journal of Cleaner Production 62, 24-36. https://doi.org/10.1016/ j.jclepro.2013.03.042

Horn, R., De Klerk, M. \& De Villiers, C., 2018, 'The association between corporate social responsibility reporting and firm value for South African firms', South African Journal of Economic and Management Sciences 21(1), 1-10. https://doi. org/10.4102/sajems.v21i1.2236

International Integrated Reporting Council (IIRC), 2013, The International $\langle I R>$ framework. www.theiirc.org.

Institute of Directors Southern Africa (IoDSA), 2009, King report on governance for South Africa 2009, IoDSA, Johannesburg.

Institute of Directors Southern Africa (IODSA), 2016, King IV. Report on corporate governance for South Africa 2016, IoDSA, Johannesburg.
James, M.L., 2014, 'The benefits of sustainability and integrated reporting: An investigation of accounting majors' perceptions', Journal of Legal, Ethical and Regulatory Issues 17(2), 93-113.

Johnson, R., Mans-Kemp, N. \& Erasmus, P.D., 2019, 'Assessing the business case for environmental, social and corporate governance practices in South Africa', South African Journal of Economic and Management Sciences 22(1), 1-13. https://doi. org/10.4102/sajems.v22i1.2727

Kamp-Roelands, N., 2013, 'Commentary on "Integrated reporting: A review of developments and their implications for accounting curriculum"', Accounting Education: An International Journal 22(4), 357-359. https://doi.org/10.1080/096 39284.2013.817799

Kavanagh, M.H. \& Drennan. L., 2008, 'What skills and attributes does an accounting graduate need? Evidence from student perception sand employer expectations' Accounting and Finance 48(2), 279-300. https://doi.org/10.1111/j.1467-629X 2007.00245.x

Lander, M.W., Koene, B.A.S. \& Linssen, S.N., 2013, 'Committed to professionalism Organizational responses of mid-tier accounting firms to conflicting institutional logics', Accounting, Organizations and Society 38(2), 130-148. https://doi. org/10.1016/j.aos.2012.11.001

Laine, M., 2013, 'A commentary on "Sustainability and accounting education: The elephant in the classroom"', Accounting Education: An International Journal 22(4), 333-335. https://doi.org/10.1080/09639284.2013.817796

Lawson, R.A., Blocher, E.J., Brewer, P.C., Cokins, G., Sorenson, J.E., Stout, D.E. et al., 2014 'Focusing accounting curricula on students' long-run careers: Recommendations for an integrated competency-based framework for accounting education', Issues in Accounting Education 29(2), 295-317. https://doi.org/10.2308/iace-50673

Le Roux, C. \& Pretorius, M., 2019, 'Exploring the nexus between integrated reporting and sustainability embeddedness', Sustainability Accounting, Management and Policy Journal 10(5), 822-843. https://doi.org/10.1108/SAMPJ-02-2018-0049

Litowitz, D., 2000, 'Gramsci, hegemony, and the law', BYU Law Review 2000(2), 515.

Lungu, C.I., Caraiani, C. \& Dascălu, C., 2012, 'Integrating sustainability into the accounting education: A fashionable of necessary change?', Proceedings of the 7 th International Conference, Accounting and Management Information Systems, AMIS 2012, 13rd-14th June, Bucharest.

Malola, A. \& Maroun, W., 2019, 'The measurement and potential drivers of integrated report quality: Evidence from a pioneer in integrated reporting', South African Journal of Accounting Research 33(2), 114-144. https://doi.org/10.1080/102919 54.2019.1647937

Marx, B. \& Van der Watt, A., 2013, 'Sustainability in accounting education: An analysis of the teaching thereof at accredited South African universities', $S A$ Journal of Accounting Research 27(1), 59-85. https://doi.org/10.1080/10291954. 2013.11435171

Mayo, P., 2008, 'Antonio Gramsci and his relevance for the education of adults', Education Philosophy and Theory 40(3), 418-435. https://doi.org/10.1111/j. 1469-5812.2007.00357.x

Mezirow, J., 2003, 'Transformative learning as discourse', Journal of Transformative Education 1(1), 58-63. https://doi.org/10.1177/1541344603252172

McNally, M.A., Cerbone, D. \& Maroun, W., 2017, 'Exploring the challenges of preparing an integrated report', Meditari Accountancy Research 25(4), 481-504. https://doi. org/10.1108/MEDAR-10-2016-0085

McPhail, K., 1999, 'The threat of ethical accountants: An application of Foucault's concept of ethics to accounting education and some thoughts on ethically educating for the other', Critical Perspectives in Accounting 10(6), 833-866. educating for the other', Critical Perspect
https://doi.org/10.1006/cpac.1998.0277

Mmako, N. \& Van Rensburg, M.J., 2017, 'Towards integrated reporting: The inclusion of content elements of an integrated annual report in the chairmen's statements
of JSE-listed companies', South African Journal of Business Management 48(1), 45-54. https://doi.org/10.4102/sajbm.v48i1.19

Morrell, J., 1986, 'The cultural meaning of popular science: Phrenology and the organization of consent in the nineteenth-century Britain by R Cooter', Social Studies of Science 16(4), 735-745. https://doi.org/10.1177/030631286016004010

Nadler, J., Thompson, L. \& Van Boven, L., 2003, 'Learning negotiation skills: Fou models of knowledge creation and transfer', Management Science 49(4), 529-540. https://doi.org/10.1287/mnsc.49.4.529.14431

Naeem, M. \& Neal, M., 2012, 'Sustainability in business education in the Asia Pacific region: A snapshot of the situation', International Journal of Sustainability in Higher Education 13(1), 60-71. https://doi.org/10.1108/14676371211190317

Naynar, N.R., Ram, A.J. \& Maroun, W., 2018, 'Expectation gap between preparers and stakeholders in integrated reporting', Meditari Accountancy Research 26(2), 241-262. https://doi.org/10.1108/MEDAR-12-2017-0249

O'Dwyer, B. \& Unerman, J., 2016, 'Fostering rigour in accounting for social sustainability', Accounting, Organizations and Society 49, 32-40. https://doi.org/10.1016/j. accounting, Organi

Owen, G., 2013a, 'Integrated reporting: A review of developments and their implications for accounting curriculum', Accounting Education: An Internationa Journal 22(4), 340-356. https://doi.org/10.1080/09639284.2013.817798

Owen, G., 2013b, 'A rejoinder to commentaries on "Integrated reporting: A review of developments and their implications for accounting curriculum"', Accounting Education: An International Journal, 22(4), 363-365. https://doi.org/10.1080/096 39284.2013.817801

Pathways Commission, 2012, Charting a national strategy for the next generation of accountants, viewed 25 May 2015, from http://commons.aaahq.org/posts/ $5 \mathrm{f} 7 \mathrm{da03fab}$

Raemaekers, K., Maroun, W. \& Padia, N., 2016, 'Risk disclosures by South African listed companies post-King III', South African Journal of Accounting Research 30(1), 41-60. https://doi.org/10.1080/10291954.2015.1021583 
Rezaee, Z. \& Homayoun, S., 2014, 'Integrating sustainability education in business curriculum: An analysis of existing syllabi', Journal of Business and Economics 8(10), 1877-1891.

Rosinko, C.A. \& Sama, L.M., 2009, 'Greening and sustainability across the management curriculum: An extended journey', Journal of Management Education 33(3), 271-275. https://doi.org/10.1177/1052562908327639

Salovey, P. \& Mayer, J.D., 1990, 'Emotional intelligence', Imagination, Cognition and Personality 9(3), 185-211. https://doi.org/10.2190/DUGG-P24E-52WK-6CDG

Saravanamuthu, K., 2015, 'Instilling a sustainability ethos in accounting education through the transformative learning pedagogy: A case-study', Critical Perspectives in Accounting 32, 1-36. https://doi.org/10.1016/j.cpa.2015.05.008

Solomon, J. \& Maroun, W., 2012, Integrated reporting: The influence of King III on social, ethical and environmental reporting, ACCA, London.

Spence, C., 2007, 'Social and environmental reporting and hegemonic discourse', Accounting, Auditing and Accountability Journal 20(6), 855-882. https://doi. org/10.1108/09513570710830272

Spence, C., 2009, 'Social accounting's emancipatory potential: A Gramscian critique', Critical Perspectives in Accounting 20(2), 205-227. https://doi.org/10.1016/j. сра.2007.06.003
Stoddart, M.C.J., 2007, 'Ideology, hegemony, discourse: A critical review of theories of knowledge and power', Social Thought and Research 28, 191-225. https://doi. org/10.17161/STR.1808.5226

Stubbs, W. \& Higgins, C., 2014, 'Integrated reporting and internal mechanisms of change', Accounting, Auditing and Accountability Journal 27(7), 1068-1089. https://doi.org/10.1108/AAAJ-03-2013-1279

Thomson, I. \& Bebbington, J., 2004, 'It doesn't matter what you teach?', Critical Perspectives on Accounting 15(4-5), 609-628. https://doi.org/10.1016/S10452354(03)00049-2

Venter, E.R. \& De Villiers, C., 2013, 'The accounting profession's influence on academe: South African evidence', Accounting, Auditing and Accountability Journal 26(8),
1246-1278. https://doi.org/10.1108/AAAJ-06-2012-01027

Xu, L., Cortese, C. \& Zhang, E., 2013, 'Exploring hegemonic change in China: A case of accounting evolution', Asian Review of Accounting 21(2), 113-127. https://doi. org/10.1108/ARA-04-2012-0016

Yee, H., 2009, 'The re-emergence of the public accounting profession in China: A hegemonic analysis', Critical Perspectives in Accounting 20(1), 71-92. https:// doi.org/10.1016/j.cpa.2007.03.008

Zulkifli, N., 2011, 'Social and environmental accounting education and sustainability: Educators' perspectives', Journal of Social Sciences 7(1), 76-89. https://doi. org/10.3844/jssp.2011.76.89 